\title{
Clinical efficacy of a cosmetic formulation with vitamin B3 for the treatment of oily skin
}

\author{
Eficácia clínica de uma formulação cosmética contendo vitamina B3 para o tratamento da \\ pele oleosa
}

\section{Marcella Gabarra Almeida Leite \& Patrícia Maria Berardo Gonçalves Maia Campos*}

Faculdade de Ciências Farmacêuticas de Ribeirão Preto, Universidade de São Paulo, Av. do Café S/N, Monte Alegre, 14040-903, Ribeirão Preto, SP, Brasil

*corresponding author / autor para correspondência: pmcampos@usp.br

\begin{abstract}
Oily skin has special needs, as the treatment and prevention of non-inflammatory acne and sebum control, maintaining skin barrier function and hydration. In this context, the importance of the development of specific and innovative cosmetics formulations to to fulfill the needs of this type of skin is evident. In this view, the aim of this study was the evaluation of the clinical efficacy of a cosmetic formulation containing Vitamin B3 in the treatment of oily skin using biophysical and skin imaging techniques. Female volunteers $(n=40)$ between 18 to 30 years old with oily skin and/ or mild inflammatory acne were recruited and received a formulation containing, or not (vehicle), 3\% of Vitamin B3. Stratum corneum water content, transepidermal water loss (TEWL), sebum content and quantity of porphyrins were analyzed before (baseline) and after 28 days of application. Finally, an efficacy perception questionnaire was applied at the study end. The formulation with vitamin B3, showed a significant reduction of sebum and porphyrin content. The study participants in the assessment of perceived efficacy also reported these results. The studied formulation with Vitamin B3 was effective for oily skin care, acting on important parameters, such as controlling oiliness and improving skin appearance.
\end{abstract}

Keywords: cosmetics, Niacinamide, skin physiology, oily skin, biophysical and skin imaging

\begin{abstract}
o
A pele oleosa apresenta necessidades especiais, como o tratamento e a prevenção da acne inflamatória e controle do sebo, sem comprometer a integridade da função barreira e hidratação. Assim, a importância do desenvolvimento de formulações cosméticas específicas e inovadoras para esse tipo de pele, adequadas as suas necessidades, é evidente. Nesse contexto, o objetivo do presente estudo foi a avaliação da eficácia clínica de formulações contendo vitamina B3 para o tratamento da pele oleosa por meio de técnicas de biofísica e análise de imagem. Participantes do sexo feminino $(\mathrm{n}=40)$, idade entre 18 e 30 anos, pele oleosa e/ou acne inflamatória foram selecionadas para o estudo e receberam a formulação contendo ou não (veículo) 3\% de vitamina B3. Foram avaliados o conteúdo aquoso do estrato córneo, TEWL, conteúdo de sebo e porfirinas e aplicado um questionário da eficácia percebida. A formulação contendo vitamina B3 mostrou redução significativa no conteúdo de sebo e porfirinas. Esses resultados também foram relatados pelas participantes na avaliação da eficácia percebida.A vitamina B3 foi efetiva para a aplicação em formulações para os cuidados da pele oleosa, atuando em parâmetros importantes, como o controle da oleosidade e melhora da aparência da pele.
\end{abstract}

Palavras-chave: cosméticos, Niacinamida, fisiologia da pele, pele oleosa, biofísica e análise de imagem da pele 


\section{Introduction}

Oily skin, also known as seborrhea, is one of the most common skin issues, most common in teenagers and young adults. In this type of skin, the sebaceous glands are characteristically oversized, leading to an excessive production of sebum, which causes a shiny and greasy appearance and can collaborate with the appearance of acne (1). It is also described as a thickening of the skin with the presence of enlarged pores, being more visible on the nose and forehead regions (2). These characteristics are usually esthetically disturbing, and are perceived as a serious cosmetic problem, with a negative influence on quality of life and self-perception (3).

This condition also requires special needs, as well as the treatment and prevention of non-inflammatory acne and control of sebum content, along with the integrity of skin barrier function and hydration. In this way, the application of vitamins in cosmetic formulations is an excellent alternative of treatment for this skin condition, and thus an important topic of interest for dermatological research.

Vitamin B3, also called Niacinamide, is described in the literature due to its many properties on the skin, including antiinflamatory, antipruritic, lightening, sebostatic and antimicrobial effects (4).

A study from Khodaeian and collaborators (2013) compared the use of vitamin B3 with clindamycin, which is extensively used in the dermatological field for the treatment of inflammatory acne and observed great results. This was also described by Shalita et al. (1995), reporting its use as a good alternative to the use of antibiotics and more advantageous due to the other reported benefits to the skin $(5,6)$.

Nicotinamide, which is an amide form of vitamin B3, has the capacity of boosting cellular energy. It also regulates poly-ADP-ribose-polymerase 1, an enzyme with important roles in DNA repair and in the expression of inflammatory cytokines, which are useful for the treatment of a wide range of dermatological conditions, including acne (7).

In this context, vitamin B3 has potential benefits for the treatment of oily skin conditions, controlling the pathogenic factor of acne (Cutibacterium acnes) given to Niacinamide's antimicrobial properties as well as controlling the excessive production of sebum.

\section{Introdução}

A pele oleosa, também denominada seborreia, é uma das alterações mais comuns, acontecendo principalmente na adolescência e em jovens adultos. Nesse tipo de pele, as glândulas sebáceas se apresentam aumentadas, o que leva a uma produção excessiva de sebo, causando uma aparência brilhante e oleosa, podendo promover a formação de acne (1). É também descrita com um aumento da espessura da pele, com a presença de poros largos, se apresentando mais visíveis nas regiões do nariz e testa (2). Essas características são consideradas esteticamente perturbadoras e são consideradas um sério problema cosmético, apresentando influencia na qualidade de vida e auto percepção de forma negativa (3).

Essa condição apresenta necessidades especiais, assim como o tratamento e a prevenção da acne não inflamatória e o controle do sebo, em conjunto com a manutenção da integridade da função barreira da pele e hidratação. Dessa forma, a aplicação de vitaminas em formulações cosméticas é uma excelente alternativa para o tratamento dessa condição, sendo um tópico de interesse na pesquisa dermatológica.

A vitamina B3, também chamada de Niacinamida, é descrita na literatura devidoas suas diversas propriedades no tratamento da pele. Estudos relatam que a vitamina B3 possui propriedades anti-inflamatória, antipruritica, clareadora, sebostática e antimicrobiana (4).

Um estudo de Khodaeian e colaboradores (2013) comparou o uso da vtiamina B3 com o da clindamicina, a qual vem sendo usada extensivamente no campo dermatológico para o tratamento da acne inflamatória e promovendo bons resultados. Essa comparação também foi descrita por Shalita et al (1995), se apresentando como uma boa alternativa para o uso de antibióticos e mais vantajosa, devido aos outros benefícios relatados para a pele $(5,6)$.

Nicotinamida, a forma amida da vitamina B3, apresenta a capacidade de aumentar a energia celular e também regular a poli-ADP-ribose-polimerase 1, uma enzima que apresenta um papel importante no reparo do DNA e expressão de citocinas inflamatórias, o que é de grande importância para o tratamento de uma série de condições dermatológicas, incluindo a acne (7).

Nesse contexto, a vitamina B3 apresenta potenciais benefícios para o tratamento das condições da pele oleosa, controlando o fator patogênico da acne (Cutibacterium acnes), devido a função antimicrobiana da Niacinamida, assim como propriedades no controle da secreção de sebo. 
Finally, considering that a previous study of our research group showed the benefits of the application of vitamin B3 in association with vitamin B6 and ZincPCA in the treatment of oily skin with inflammatory acne (8), the aim of the present study was to evaluate the clinical efficacy of formulations containing vitamin B3 for the treatment of oily skin using biophysical and skin imaging techniques.

\section{Materials and Methods}

\section{Studied Formulation}

Two topical formulations of gel creams based on xanthan gum, tribehenine esters PEG-20, octyldodecyl myristate, polypropylene and sorbitan PEG-10, added or not (vehicle) with 3\% vitamin B3 - nicotinamide (Table 1) were prepared.

\section{Study design}

The present study was a monocentric, double-blinded, randomized, placebo-controlled study on the effects of a cosmetic formulation with added Vitamin B3 on oily skin after four weeks of treatment. The study was approved by the Ethics Committee of the Faculty of Pharmaceutical Sciences of Ribeirão Preto/SP (CEP / FCFRP 248/2012) and followed current Good Clinical Practice regulations.

All test subjects received detailed information listing every single relevant parameter to the study and all the procedures involved. All subjects gave signed informed consent after written information and a possibility for further questioning. The study was performed in accordance with the ethical standards of the Declaration of Helsinki of 1975, as revised in 2013.

\section{Participants}

A total of 40 healthy female subjects were enrolled in the study: 20 subjects were randomized to each of two treatment groups using the cosmetic formulations under study, which included or not 3\% Vitamin B3 (Nicotinamide). The volunteers were instructed to apply the formulation to the face twice daily for a period of four weeks. Baseline and final measures were done in the frontal (forehead), malar (cheeks) and chin regions.
Por fim, considerando um estudo anterior do nosso grupo de pesquisa que mostrou os benefícios da aplicação da vitamina $\mathrm{B} 3 \mathrm{em}$ associação com a vitamina B6 e Zn-PCA no tratamento da pele oleosa com acne inflamatória (8), o objetivo do presente estudo foi avaliar a eficácia clínica de uma formulação cosmética contendo vitamina B3 para o tratamento da pele oleosa por meio de técnicas de biofísica e análise de imagem da pele.

\section{Material e Métodos}

\section{Formulações estudada}

Foram elaboradas duas formulações tópica de creme de gel à base de goma xantana, ésteres de tribehenina PEG-20, miristato de octildodecil, polipropileno e sorbitano PEG - 10, adicionada ou não (veículo) com $3 \%$ de vitamina B3 - nicotinamida (Tabela 1 ).

\section{Design de estudo}

O presente estudo foi um estudo monocêntrico, duplocego, randomizado, controlado, placebo, sobre os efeitos de formulações cosméticas adicionadas com vitamina B3 na pele oleosa após quatro semanas de tratamento. O estudo foi aprovado pelo Comitê de Ética da Faculdade de Ciências Farmacêuticas de Ribeirão Preto / SP (CEP / FCFRP 248/2012) e seguiu os regulamentos atuais de Boas Práticas Clínicas.

Todos os sujeitos do teste receberam informações detalhadas listando todos os parâmetros relevantes para o estudo e todos os procedimentos envolvidos. Todos os sujeitos assinaram o termo de consentimento livre e esclarecido após informações por escrito e a possibilidade de mais questionamentos. Este estudo foi realizado de acordo com os padrões éticos da Declaração de Helsinque de 1975, revisada em 2013.

\section{Participantes}

Um total de 40 indivíduos saudáveis do sexo feminino foram incluídos no estudo: 20 indivíduos foram randomizados para cada um dos dois grupos de tratamento para usar as formulações cosméticas em estudo que foi adicionada ou não com 3\% de vitamina B3 (nicotinamida). Os voluntários foram instruídos a aplicar a formulação na região facial, duas vezes ao dia por um período de quatro semanas. As medidas basais e finais foram realizadas nas regiões frontal (testa), malar (bochechas) e queixo. 
Table 1 - Composition of studied formulations

Tabela 1 - Composição das formulações estudadas

\begin{tabular}{|c|c|}
\hline $\begin{array}{c}\text { Composition / Composição } \\
\text { (INCI Name) }\end{array}$ & Supplier / Fornecedor \\
\hline "Tribehenin Esters PEG-20 & "(Emulium ${ }^{\circledR} 22$, Gatefossé), \\
\hline Xanthan gum & $\mathrm{CP} \mathrm{Kelco}^{\circledR}$ \\
\hline Butylene glycol & Mapric $^{\mathbb{R}}$ \\
\hline Propylene glycol & Mapric $^{\circledR}$ \\
\hline Octyldodecyl Myristate & MOD $^{\circledR}$, Gatefossé \\
\hline PEG - 10 Sorbitan & Tween $^{\circledR}$ 20, Mapric \\
\hline Butylated hydroxytoluene & BHT, Mapric ${ }^{\circledR}$ \\
\hline Cyclopentasiloxane & $\mathrm{DC}^{\circledR}$ 245, Dow Corning \\
\hline Water / Aqua & - \\
\hline $\begin{array}{c}\text { Phenoxyethanol, Methylparaben, } \\
\text { Ethylparaben, Propylparaben and } \\
\text { Butylparaben }\end{array}$ & Chemynol $^{\circledR}$, Chemyunion \\
\hline Vitamin B3 / Vitamina B3 & Niacinamide $P^{\circledR}{ }^{\circledR}, D S M$ \\
\hline
\end{tabular}

The inclusion criteria for this study were healthy females ranging in age from 18-30 years (homogeneous distribution between treatment groups); presenting oily skin and acne, phototype II-IV (Fitzpatrick scale); general good health and mental condition; avoid sun exposure during the study period; personal informed consent to participate in the study; personal presence on the predefined days at the institute, and willingness and capability to follow the study rules and a fixed schedule, know that the data could be used to share the project. The study participants were also instructed not to use other cosmetic products and to maintain their alimentary habits during the study period.

The exclusion criteria was as follows: any deviation from the above-mentioned inclusion criteria: pregnancy (or intention to become pregnant) or in period of breast feeding; skin diseases (e.g., atopic eczema, neurodermatitis or psoriasis) on the test areas or other dermatological disorders (e.g., scars, sunburn or moles), whose therapy could influence the results of the study, such as systemic steroids or antibiotics, steroids or local immunomodulatory topics three months prior to the study; smoking habit; severe disorders within 6 months prior to study start (e.g., cancer, acute cardiac and circularity disorders, severe diabetes, or alcohol or drug abuse); history of medical or surgical events that could significantly affect the outcome of the study, including any cardiovascular disease, skin disease, gastrointestinal diseases, indigestion, hypertension (>160/95 mm Hg on repeated measurements); participation in any other
Os critérios de inclusão para este estudo foram mulheres saudáveis, com idade entre 18 e 30 anos (distribuição homogênea entre os grupos de tratamento), apresentando pele oleosa e acne, fototipo II-IV (escala de Fitzpatrick); boa saúde geral e condição mental; evitar a exposição ao sol durante o período do estudo; consentimento pessoal informado para participar do estudo; presença pessoal nos dias predefinidos no instituto e disposição e capacidade de seguir as regras do estudo e um cronograma fixo, informadas de que os dados podem ser usados para compartilhar o projeto. Também foi instruído aos participantes do estudo que não usassem outros produtos cosméticos e que não mudassem seus hábitos alimentares durante o período do estudo.

Os critérios de exclusão foram os seguintes: qualquer desvio dos critérios de inclusão mencionados acima: gravidez (ou intenção de engravidar) ou no período de amamentação; doenças de pele (por exemplo, eczema atópico, neurodermatite ou psoríase) nas áreas de teste ou outros distúrbios dermatológicos (por exemplo, cicatrizes, queimaduras ou moles), cuja terapia pode influenciar os resultados do estudo, como esteróides sistêmicos ou antibióticos, esteróides ou agentes locais tópicos imunomoduladores três meses antes do estudo; hábito de fumar; distúrbios graves dentro de 6 meses antes do início do estudo (por exemplo, câncer, distúrbios cardíacos e de circularidade agudos, diabetes grave ou abuso de álcool ou drogas); histórico de eventos médicos ou cirúrgicos que podem afetar significativamente o resultado do estudo, incluindo 
clinical study; medical treatments on the study area 30 days before the study start; use of tanning beds or self-tanning products a month before or during the study; any other condition that, in the opinion of the investigator, may interfere with the results or involve a risk to the subject (9).

\section{Assessments}

The test areas were frontal (forehead), malar (cheeks) and chin regions, with sides randomly chosen. Prior to every measurement, the subjects were required to expose their uncovered test areas to the indoor climate conditions $\left(21.5 \pm 1{ }^{\circ} \mathrm{C}\right.$ and $50 \pm 5 \%$ relative humidity) for $20 \mathrm{~min}$.

Measurements were made immediately before starting the product treatment (baseline values) and after 14 (t14) and 28 days (t28) of study.

The transepidermal water loss (TEWL) measurement was carried out with a Tewameter ${ }^{\circledR}$ TM 210 (Courage Khazaka, Electronic GmbH, Germany), which measures the percentage relative humidity at the skin surface. It uses a sensing electrode encased in a proper probe and is based on the principles described by Adolf Fick in 1885 . The values are registered in $\mathrm{g} / \mathrm{m}^{2} \cdot \mathrm{h}$. The probe of the device remained in contact with the skin to obtain 45 measurements in three study areas. Three measurements were made in each study area and the average of the obtained values was calculated (10).

The casual sebum level was determined with a photometric device (Sebumeter ${ }^{\circledR}$ SM 815, Courage+Khazaka, Cologne, Germany). A special opaque plastic tape $\left(64 \mathrm{~mm}^{2}\right)$ was pressed onto the skin for $30 \mathrm{~s}$ with a slight pressure to collect the sebum. The resulting increase in the transparency of the tape was measured, where the displayed values correspond to the sebum amount on the skin surface in micrograms of sebum per square centimeter (11).

To count porphyrins in follicular surface, a Visiopor ${ }^{\circledR}$ PP 34 system (Courage+Khazaka, Cologne, Germany) was used. It uses a specific UV-light camera to visualize the lesions of acne fluorescent an area of $8 \times 10 \mathrm{~mm}$. Three images were obtained at the same location in each region (forehead, cheek, and chin) and conducted by counting the number of orange-red fluorescent spots in each image using the device's software. These points are porphyrin's endogenous metabolites of the bacteria $P$. acnes. Statistical analysis was used to average points scored between the three images (12). qualquer doença cardiovascular, doença de pele, doenças gastrointestinais, indigestão, hipertensão (> 160/95 mm $\mathrm{Hg}$ em medições repetidas); participação em qualquer outro estudo clínico; tratamentos médicos na área de estudo 30 dias antes do início do estudo; uso de camas de bronzeamento ou produtos de autobronzeamento um mês antes ou durante o estudo; qualquer outra condição que, na opinião do investigador, possa interferir nos resultados ou envolva um risco para o sujeito (9).

\section{Avaliação clínica}

As áreas de teste foram as regiões frontal (testa), malar (bochechas) e queixo, com os lados escolhidos aleatoriamente. Em todas as medições, as participantes tiveram que expor suas áreas de teste descobertas às condições climáticas internas $\left(21,5 \pm 1{ }^{\circ} \mathrm{C}\right.$ e $50 \pm 5 \%$ de umidade relativa) por 20 minutos.

Foram realizadas medidas imediatamente antes de iniciar o tratamento (valores basais) e após 14 (t14) e 28 dias (t28) de estudo.

A medição da perda de água transepidérmica (TEWL) foi realizada por meio do Tewameter ${ }^{\circledR}$ TM 210 (Courage Khazaka, Electronic GmbH, Alemanha), que mede a porcentagem de umidade relativa na superfície da pele. Utiliza um eletrodo sensor envolto em uma sonda adequada, com base nos princípios descritos por Adolf Fick em 1885. Os valores são registrados em $\mathrm{g} / \mathrm{m}^{2} . \mathrm{h}$. A sonda do dispositivo permanece em contato com a pele para obter 45 medidas em três áreas de estudo. Três medidas foram feitas em cada área de estudo e calculou a média dos valores obtidos (10).

O nível de sebo casual foi determinado com um dispositivo fotométrico (Sebumeter ${ }^{\circledR}$ SM 815, Courage + Khazaka, Colônia, Alemanha). Uma fita plástica opaca especial $\left(64 \mathrm{~mm}^{2}\right)$ foi pressionada sobre a pele por $30 \mathrm{~s}$ com uma leve pressão para coletar o sebo. O aumento resultante na transparência da fita foi medido e os valores exibidos correspondem à quantidade de sebo na superfície da pele em microgramas de sebo por centímetros quadrados (11).

Para contagem de porfirinas na superfície folicular foi utilizado o equipamento Visiopor ${ }^{\circledR}$ PP 34. Este equipamento, utiliza uma câmera de luz UV específica para visualizar as lesões da acne fluorescente em uma área de $8 \times 10 \mathrm{~mm}$. Três imagens foram obtidas no mesmo local em cada região e conduzidas contando o número de pontos fluorescentes vermelho-alaranjado em cada imagem através do próprio software do dispositivo. Esses pontos são metabólitos endógenos 
Finally, at the end of the study, perception of efficacy was analyzed through a questionnaire that compared and analyzed the skin before and after treatment in terms of reducing oiliness, blackheads, acne and improvement in skin hydration and smoothness.

\section{Statistical Analysis}

The statistical analysis was performed according to the data distribution. For the normal distribution, the ANOVA test was applied. For the nonparametric, the Friedman test was performed using the GraphPad Prism 5 software.

\section{Results and Discussion}

After statistical analysis of the parameters evaluated in the long-term efficacy study, it was observed that the formulation containing vitamin B3 showed a significant reduction of the amount of sebum after 28 days of application when compared to baseline values (Figure 1). This effect was not observed in the groups utilizing the vehicle. das porfirinas da bactéria $P$. acnes. A análise estatística foi usada para a média de pontos marcados entre as três imagens (12).

Por fim, foi realizada após o final do estudo uma análise da percepção de eficácia por meio de um questionário que comparava e analisava a pele antes e após o tratamento em termos de redução da oleosidade, cravos, acne e melhora da hidratação e suavidade da pele.

\section{Análise Estatística}

A análise estatística foi realizada de acordo com a distribuição dos dados, sendo que para uma distribuição normal aplicou-se o teste paramétrico ANOVA e não normal, o teste não paramétrico, Friedman, realizado pelo software GraphPad Prism 5.

\section{Resultados e Discussão}

Após análise estatística dos parâmetros avaliados no estudo de eficácia em longo prazo, observou-se que a formulação contendo vitamina B3 promoveu redução significativa da quantidade de sebo após 28 dias de aplicação em comparação com os valores basais (Figura 1). Este efeito não foi observado no grupo que utilizou a formulação veículo.

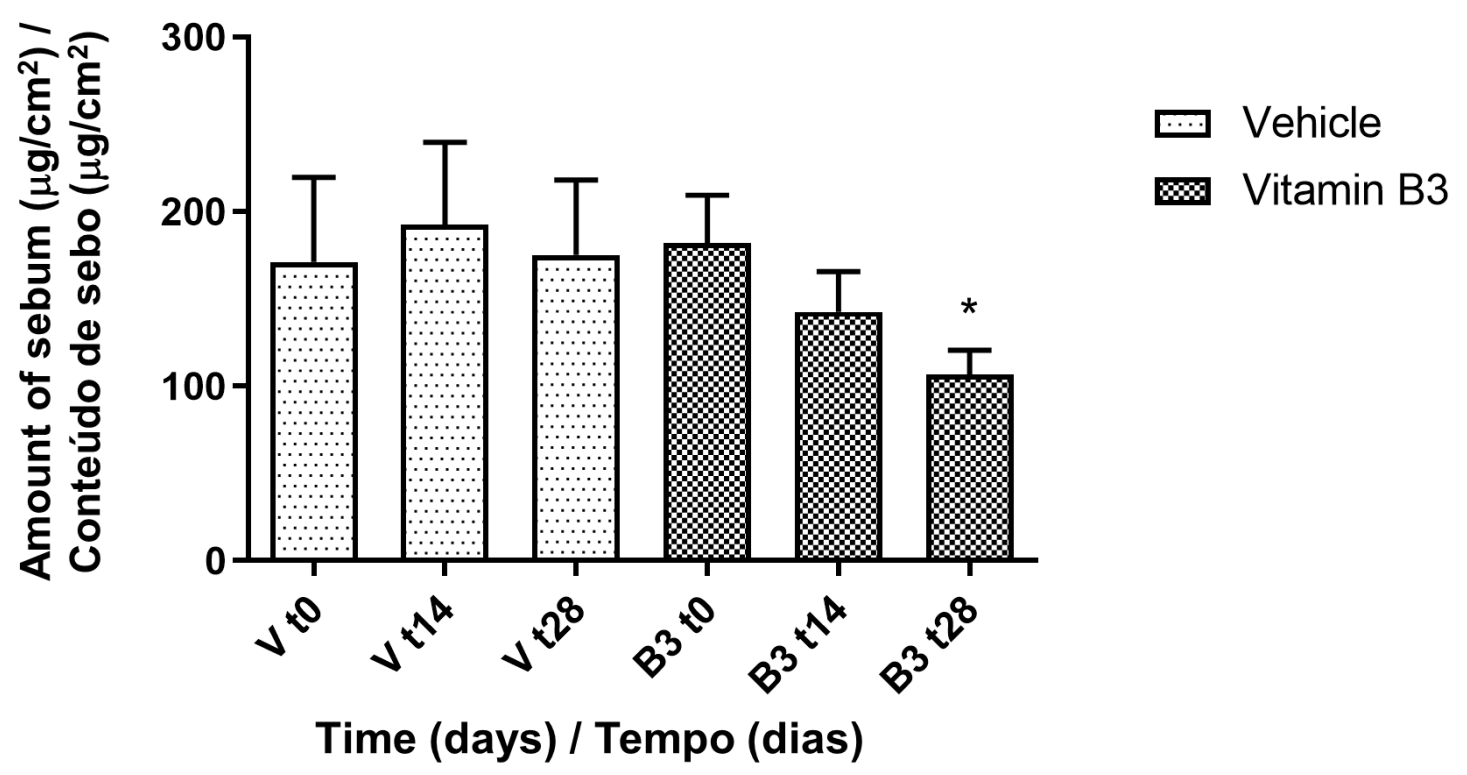

Figure 1 - Sebum content on the frontal region before (baseline values - t0) and after application during 14 (t14) and 28 (t28) days of treatment with the Vehicle - V and with the formulation containing 3\% of vitamin B3 - B3. *Significantly different from the baseline values $(\mathrm{p}<0.05)$.

Figura 1 - Conteúdo de sebo na região frontal antes (valores basais - t0) e após a aplicação durante 14 (t14) e 28 dias (t28) de tratamento com as formulações Veículo - V e contendo 3\% de vitamina B3 - B3. *Significante em relação aos valores basais $(\mathrm{p}<0,05)$. 
A decrease in the number of spots of porphyrin in the group that utilized the vitamin B3 formulation was also observed (Figure 2). The statistical analysis showed that the results were more pronounced in the frontal region of the face.

No significant alterations were observed in the Transepidermal Water Loss.

In the evaluation of the perception of effectiveness, it was possible to observe that the study participants perceived a reduction in the amount of sebum, blackheads and acne after treatment with the formulation containing vitamin B3. In addition, an improvement in skin hydration and smoothness was reported (Figure 3).

Topical nicotinamide has been shown to be useful in the treatment of acne vulgaris due to its sebosuppressive, anti-inflammatory, and healing properties. The evaluation of the results showed that the topical application of formulations containing nicotinamide presented a significant reduction in the amount of sebum after and also a significant reduction in the porphyrin count after 28 days of application. This result can be explained by the reported anti-microbiological effect (13).
Também foi observada uma diminuição na contagem de porfirina no grupo que utilizou a formulação de vitamina B3 após 28 dias de tratamento (Figura 2). Além disso, a análise estatística mostrou que os resultados foram mais pronunciados na região frontal da face.

Não foram observadas alterações significativas na perda transepidermica de água.

$\mathrm{Na}$ avaliação da percepção de eficácia foi possível observar que as participantes do estudo perceberam uma redução na quantidade de sebo, cravos e acne após o tratamento com a formulação contendo vitamina B3, além de melhora na hidratação e suavidade da pele (Figura 3).

A nicotinamida tópica demonstrou ser efetiva no tratamento da acne vulgar devido ao seu efeito sebosupressor, propriedades anti-inflamatórias e curativas. A avaliação dos resultados mostrou que a aplicação tópica de formulações contendo nicotinamida apresentou uma redução significativa no conteúdo de sebo após e também uma redução significativa na contagem de porfirinas após 28 dias de aplicação. Esse resultado pode ser explicado devido ao seu efeito antimicrobiano (13).

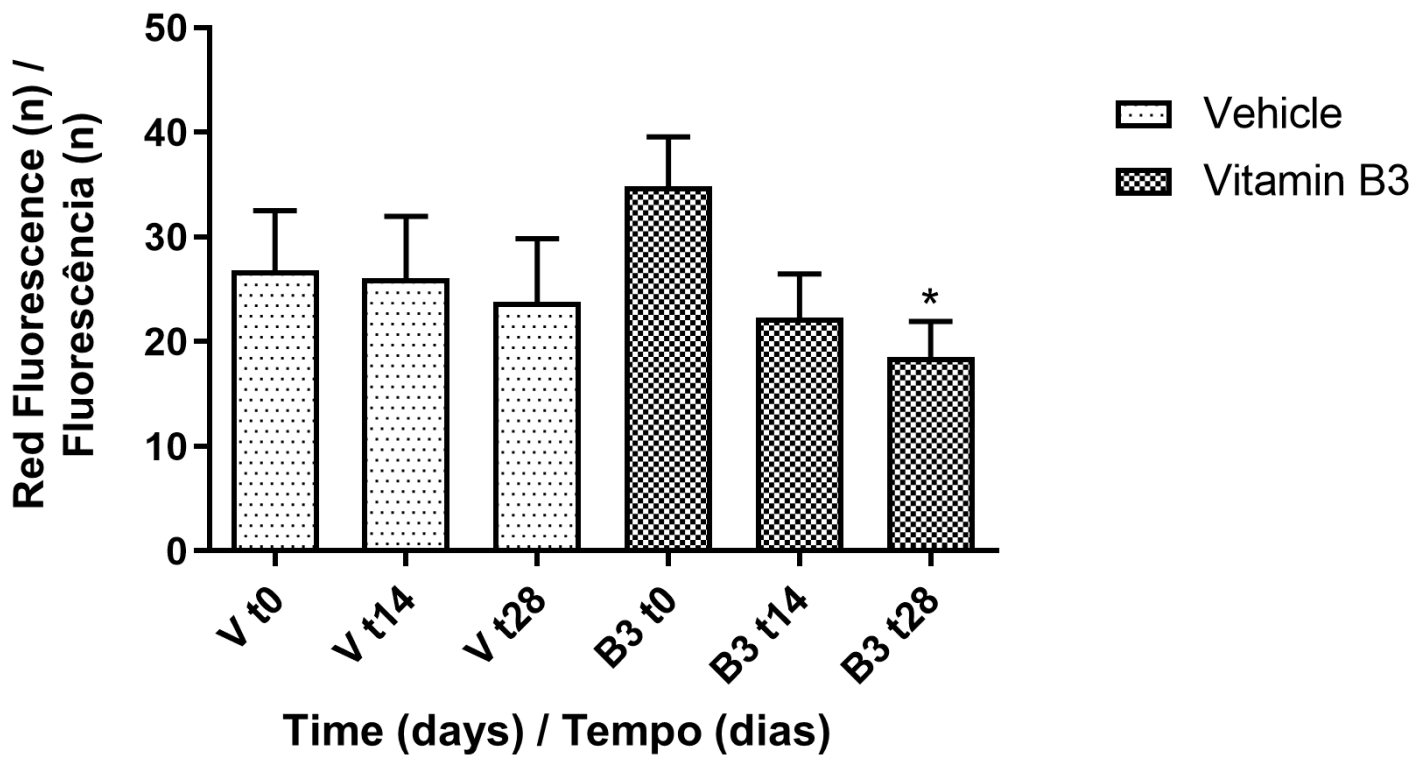

Figure 2 - Porphyrin content on the frontal region before (baseline values - t0) and after application during $14(\mathrm{t} 14)$ and 28 (t28) days of treatment with the Vehicle $-\mathrm{V}$ and with the formulation containing $3 \%$ of vitamin B3 -B3. * Significantly different from the baseline values $(\mathrm{p}<0.05)$.

Figura 2 - Conteúdo de porfirinas - fluorescência na região frontal antes (valores basais - t0) e após a aplicação durante 14 e 28 dias de tratamento com as formulações Veículo -V e contendo 3\% de vitamina B3 - B3. *Significante em relação aos valores basais $(\mathrm{p}<0,05)$. 
A previous study of our research group (12) showed that the presence and amount of porphyrins on the face are related to the secretion of sebum on the skin and a positive correlation among these features was found. In this context, the reduction of sebum along with the secretase of porphyrin count on the skin corroborates with the previous results of our research.

Alterations on the skin microbiome related to skin type have also been reported in the literature, where an increase in Cutibacterium acnes bacteria is observed in individuals with oily skin, as the bacteria consume this oil (14).

In this context, the present study showed that the use of 3\% vitamin B3 presented a significant reduction in sebum content and porphyrins spots after 28 days of application. In addition, previous studies (15) reported that topical use of nicotinamide has been shown to improve fine lines and wrinkles, hyperpigmented spots, red blotchiness, and sallowness (yellowing), as well as skin elasticity.

An increase of the skin's production of collagen and ceramides, stimulating keratinocyte differentiation, has also been reported, leading to an improvement of barrier function and skin appearance. It is important to highlight that the use of nicotinamide is comparable to topical antibiotic treatment with clindamycin gel (16), with the advantage that the side effects of nicotinamide
Um estudo anterior do nosso grupo de pesquisa (12) mostrou que a presença e a quantidade de porfirinas no rosto estão relacionadas à secreção de sebo na pele e foi encontrada uma correlação positiva entre essas características. Nesse contexto, a redução do sebo juntamente com redução da contagem de porfirinas na pele corrobora com os resultados anteriores de nossa pesquisa.

Também foi relatado na literatura que as alterações na microbiota da pele estão relacionadas ao tipo de pele, observando-se que a pele oleosa apresenta um aumento na bactéria Cutibacterium acnes devido à quantidade excessiva de óleo consumida por essa bactéria (14).

Nesse contexto, o presente estudo mostrou que o uso de 3\% de vitamina B3 apresentou uma redução significativa no conteúdo de sebo e porfirinas após 28 dias de aplicação. Além disso, estudos anteriores (15) relataram que o uso tópico de nicotinamida demonstrou melhorar as linhas finas e rugas, manchas hiperpigmentadas, manchas vermelhas e amarelamento, bem como a elasticidade da pele.

Também foi relatado um aumento da produção de colágeno e ceramidas da pele, que estimula a diferenciação de queratinócitos, levando a uma melhora da função barreira e aparência da pele. É importante destacar que o uso da nicotinamida é comparável ao tratamento antibiótico tópico com gel de clindamicina

\section{Perception of efficacy / Percepção da eficácia}

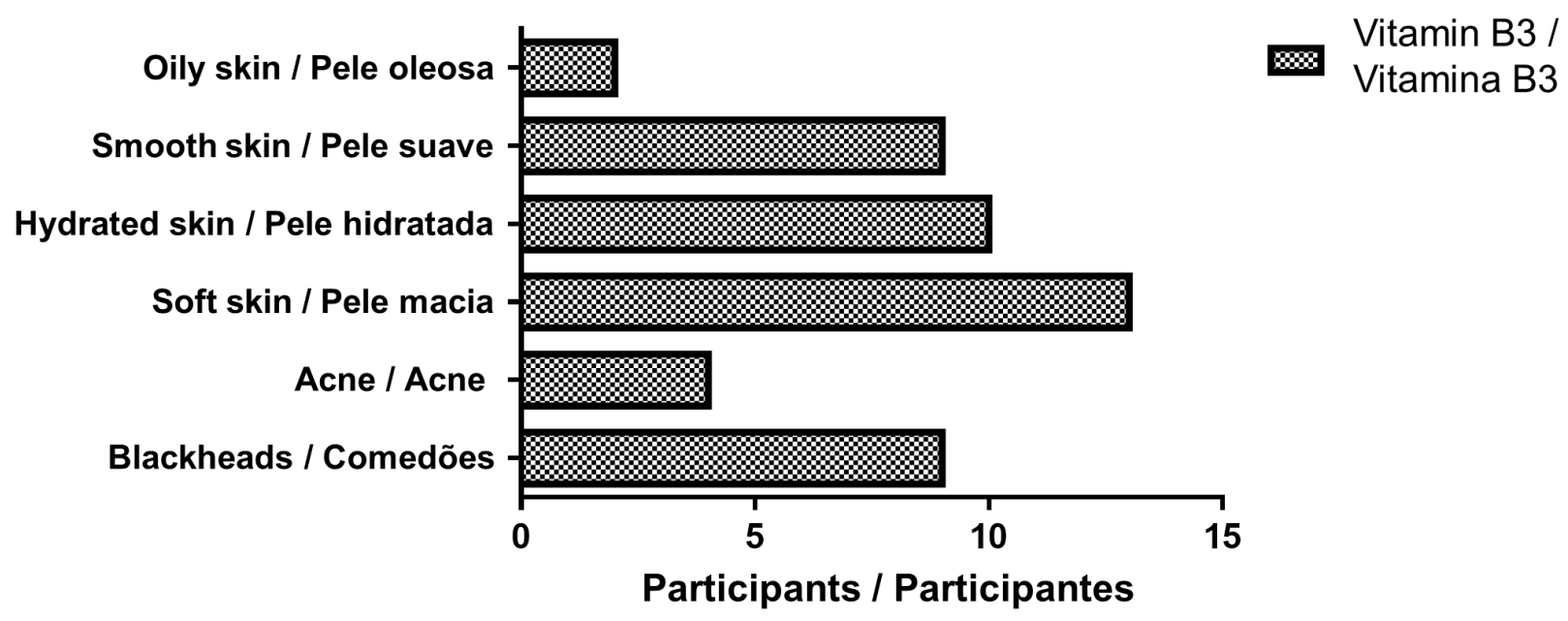

Figure 3 - Efficacy perception analysis after 28 days of treatment with the formulations containing 3\% of Vitamin B3. Figura 3 - Percepção da eficácia após 28 dias de tratamento com as formulações contendo 3\% de vitamina B3. 
are much safer than those of antibiotics substances and that it does not create antibiotic-resistant pathogens. This way, the use of vitamin B3 can be presented as an excellent alternative for the treatment of oily skin (17).

These effects have a great importance to the dermatological area as it contributes to the treatment of oily skin as a whole, without the use of any of the classical substances for these skin conditions which are usually more aggressive to skin health as a whole. Furthermore, the addition of substances that can improve the skin barrier function, keeping the maintenance of skin layers, is very important, as it does not cause damages while treating the excess of sebum.

At the same time, in the efficacy perception evaluation, the participants reported that their skin did not feel oily and a reduction in the presence of acne and blackheads was observed. Also, the participants also reported that they perceived their skin to be more hydrated, smooth and soft. The perceived efficacy is of great importance, as the observed effects by the participants support adherence to the treatment and consequently the efficacy with the application of the formulation (12).

In summary, after a statistical analysis of the obtained data, the formulation under study containing vitamin B3 showed a significant reduction of the amount of sebum when compared to baseline values. A reduction in the porphyrin count was also observed, with no alterations to the skin barrier. The applied questionnaires showed that the participants felt an improvement in the overall skin appearance and well-being while using the formulation under study.

In conclusion, the vitamin B3 was effective for application within formulations for oily skin care, reducing the amount of sebum and the porphyrin count while improving the appearance of skin and the participants well-being. Formulations containing vitamin B3 may be a excellent alternative for the treatment of oily skin, due to its complementary properties in improving skin conditions and women's quality of life.

Finally, the study has as its contribution the clinical, analytical evidence of the benefits of the topical use of vitamin B3 for the control of oily skin.
(16), com a vantagem de que os efeitos colaterais da nicotinamida são muito mais seguros que os das substâncias antibióticas e que não cria patógenos resistentes a antibióticos. Dessa forma, o uso de vitamina B3 pode ser apresentado como uma ótima alternativa ao tratamento da pele oleosa (17).

Esses efeitos têm uma grande importância para a área dermatológica, pois contribuem para o tratamento da pele oleosa como um todo, sem o uso de qualquer substância clássica para essas condições de pele, que geralmente são mais agressivas à saúde da pele como um todo. Além disso, a adição de substâncias que podem melhorar a função de barreira da pele, mantendo a manutenção das camadas da pele, é muito importante, pois não causa danos ao tratar o excesso de sebo.

Ao mesmo tempo, na avaliação da percepção de eficácia, os participantes relataram não sentir a pele oleosa e observou-se uma redução na presença de acne e cravos. Além disso, os participantes relataram perceber que a pele ficou mais hidratada e macia. A eficácia percebida é de grande importância, uma vez que os resultados obtidos nas medidas instrumentais são observados pelos participantes do estudo (18), o que auxilia na adesão ao tratamento e consequentemente na eficácia com a aplicação da formulação (12).

Em síntese, após a análise estatística dos dados obtidos, a formulação contendo vitamina B3 em estudo mostrou redução significativa da quantidade de sebo quando comparada aos valores basais. Também foi observada uma redução na contagem de porfirinas e não foram observadas alterações na barreira cutânea. Os questionários aplicados mostraram que os participantes sentiram uma melhora na aparência geral e no bemestar da pele ao usar a formulação em estudo.

Em conclusão, a vitamina B3 foi eficaz para aplicação em formulações oleosas para o cuidado da pele, reduzindo a quantidade de sebo e porfirina, melhorando a aparência da pele e o bem-estar dos participantes, sendo uma ótima alternativa para o tratamento da pele oleosa, devido às suas propriedades complementares na melhora das condições da pele e da qualidade de vida das mulheres.

Por fim, o estudo tem como contribuição a comprovação clínica dos benefícios do uso tópico da vitamina B3 para o controle da oleosidade da pele por medidas instrumentais. 


\section{Author Contributions Statement}

Study conceptualization: Patricia M.B.G. Maia Campos. Methodology: Patricia M.B.G. Maia Campos and Marcella G.A. Leite. Formal analysis: Patricia M.B.G. Maia Campos and Marcella G.A. Leite. Writing: Patricia M.B.G. Maia Campos and Marcella G.A. Leite. Writing - review and editing: Patricia M.B.G. Maia Campos.

\section{Acknowledgements}

The authors would like to express their thanks to Fapesp - Fundação de Amparo à Pesquisa do Estado de São Paulo and CNPq - Conselho Nacional de Desenvolvimento Científico e Tecnológico.

\section{Conflict of Interests}

Editors involved in this manuscripts' authorship had no participation in the review or decision process. All authors have stated that there are no financial and/or personal relationships that could represent a potential conflict of interest.

\section{Declaração dos contributos de cada autor}

Concepção e desenho do estudo: Patricia M.B.G. Maia Campos. Metodologia: Patricia M.B.G. Maia Campos e Marcella G.A. Leite. Analise formal: Patricia M.B.G. Maia Campos e Marcella G.A. Leite. Redação: Patricia M.B.G. Maia Campos e Marcella G.A. Leite. Redação - revisão e edição: Patricia M.B.G. Maia Campos.

\section{Agradecimentos}

Os autores gostariam de expressar seus agradecimentos à FAPESP- Fundação de Amparo à Pesquisa do Estado de São Paulo e CNPq - Conselho Nacional de Desenvolvimento Científico e Tecnológico.

\section{Conflito de interesses}

O Editor presente na autoria deste manuscrito não participou nos processos de pessoais revisão e/ou decisão. Os autores declararam não possuir quaisquer relações financeiras ou que possam configurar um potencial conflito de interesse. 


\section{References / Referências}

1. Sakuma, T.H., Maibach, H.I. (2012) Oily Skin: An Overview. Skin pharmacology and physiology, 25(5), 227-235. https://doi.org/10.1159/000338978

2. Nouveau-Richard, S., Zhu, W., Li, Y. H., Zhang, Y. Z., Yang, F. Z., Yang, Z. L., Lian, S., Qian, B. Y., Ran, Y. P., Bouillon, C., Chen, H. D., \& de Lacharrière, O. (2007). Oily skin: specific features in Chinese women. Skin research and technology : official journal of International Society for Bioengineering and the Skin (ISBS) [and] International Society for Digital Imaging of Skin (ISDIS) [and] International Society for Skin Imaging (ISSI), 13(1), 43-48. https://doi.org/10.1111/j.1600-0846.2006.00185.x

3. Wu, Y., Niu, Y., Zhong, S., Liu, H., Zhen, Y., Saint-Leger, D., Verschoore, M. (2013) A preliminary investigation of the impact of oily skin on quality of life and concordance of self-perceived skin oiliness and skin surface lipids (sebum). International Journal of Cosmetic Science, 35, 442-447. https://doi. org/10.1111/ics. 12063

4. Wohlrab, J., Kreft, D. (2014) Niacinamide - Mechanisms of Action and Its Topical Use in Dermatology. Skin Pharmacology and Physiology,27, 311315. https://doi.org/10.1159/000359974

5. Khodaeiani, E., Fouladi, R.F., Amirnia, M., Majid, S., Karimi, E.R. (2013) Topical 4\% nicotinamide vs. 1\% clindamycin in moderate inflammatory acne vulgaris. International Journal of Dermatology, 2013, 52: 999-1004.https://doi.org/10.1111/ijd.12002

6. Shalita, A.R., Smith, J.G., Parish, L.C. (1995) Topical nicotinamide compared with clindamycin gel in the treatment of inflammatory acne vulgaris. International Journal of Dermatology, 34, 434-437. https://doi.org/10.1111/j.1365-4362.1995.tb04449.x

7. Chen, A.C., Damian, D.L. (2014) Nicotinamide and the skin. Australasian Journal of Dermatology, 55, 169-175. https://doi.org/10.1111/ajd.12163

8. Andrade, J.P., Wagemaker, T.A.L., Mercurio, D.G., Maia Campos, P.M.B.G. (2018) Benefits of a dermocosmetic formulation with vitamins B3 and a B6 derivative combined with zinc-PCA for mild inflammatory acne and acne-prone skin. Biomedical and Biopharmaceutical Research, 15(2), 214-223. doi: $10.19277 /$ bbr.15.2.188

9. Maia Campos, P.M.B.G., Melo, M.O., Calixto, L.S., Fossa, M.M. (2015) An Oral Supplementation Based on Hydrolyzed Collagen and Vitamins Improves Skin Elasticity and Dermis Echogenicity: A Clinical Placebo-Controlled Study. Clinical Pharmacology Biopharmaceutic, 4, 142. doi:10.4172/2167065X.1000142

10. Rogiers, V., EEMCO Group. (2001) EEMCO guidance for the assessment of transepidermal water loss in cosmetic sciences. Skin Pharmacology and Physiology, 14(2), 117- 128. https://doi.org/10.1159/000056341

11. Crowther, J.M. (2015) Method for quantification of oils and sebum levels on skin using the Sebumeter ${ }^{\circledR}$. International Journal of Cosmetic Science,38, 210-216. https://doi.org/10.1111/ics.12258

12. Gabarra Almeida Leite, M., \& Maia Campos, P. (2020). Correlations between sebaceous glands activity and porphyrins in the oily skin and hair and immediate effects of dermocosmetic formulations. Journal of cosmetic dermatology, 19(11), 3100-3106. https://doi.org/10.1111/jocd.13370

13. Rolfe H. M. (2014). A review of nicotinamide: treatment of skin diseases and potential side effects. Journal of cosmetic dermatology, 13(4), 324-328. https://doi.org/10.1111/jocd.12119

14, Zheng, Y., Liang, H., Zhou, M., Song, L., He, C. (2021) Skin bacterial structure of young females in China: The relationship between skin bacterial structure and facial skin types. Experimental Dermatology, 30(10),1366-1374. https://doi.org/10.1111/exd.14105

15. Tran, D., Townley, J.P., Barnes, T.M., Greive, K.A. (2015) An antiaging skin care system containing alpha hydroxy acids and vitamins improves the biomechanical parameters of facial skin. Clinical, Cosmetic and Investigational Dermatology, 8, 9-17. https://doi.org/10.2147/CCID.S75439

16, Khodaeiani, E., Fouladi, R.F., Amirnia, M., Saeidi, M., Karimi, E.R. (2013) Topical 4\% nicotinamide vs. 1\% clindamycin in moderate inflammatory acne vulgaris. International Journal of Dermatology, 52, 999-100. https://doi.org/10.1111/ijd.12002

17. Wohlrab, J., Kreft, D. (2014) Niacinamide - Mechanisms of Action and Its Topical Use in Dermatology. Skin Pharmacology and Physiology, $27,311-315$. https://doi.org/10.1159/000359974

18. Bonilha, G.C., Costa, G.M.D. Maia Campos, P.M.B.G. (2020) Rheological, texture, and sensory analyses and in vivo clinical efficacy of cosmetic formulations containing ascorbyl tetraisopalmitate. Biomedical Biopharmaceutical Research, 17(1), 1-12. doi: 10.19277/bbr.17.1.228 